Pamiętnik Literacki 2012, 3, s. 183-193
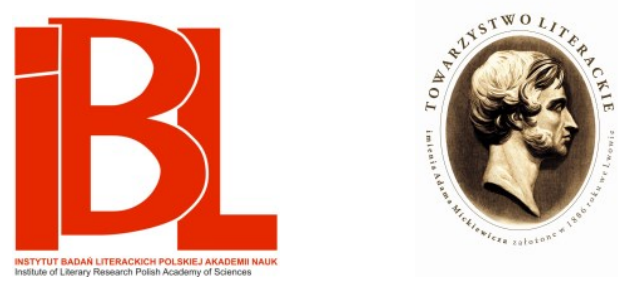

Cztery nieznane listy Marii PawlikowskiejJasnorzewskiej z lat 1935-1939

Przełożyła i opracowała Małgorzata Nossowska 


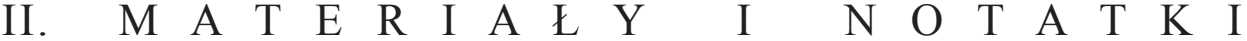 \\ Pamiętnik Literacki CIII, 2012, z. 3 PL ISSN 0031-0514
}

\section{CZTERY NIEZNANE LISTY MARII PAWLIKOWSKIEJ-JASNORZEWSKIEJ Z LAT 1935-1939}

\author{
Przełożyła i opracowała \\ MAŁGORZATA NOSSOWSKA \\ (Uniwersytet Marii Curie-Skłodowskiej, Lublin)
}

W archiwum Rosy Bailly w Bibliotece Polskiej w Paryżu pośród tysięcy innych listów znajdują się cztery, pisane po francusku (z wplecionymi gdzieniegdzie polskimi słowami), których autorką była Maria Pawlikowska-Jasnorzewska ${ }^{1}$. Listy te świadczą o dużej zażyłości łączącej obie damy oraz o intensywnej korespondencji między nimi, z której jednak niewiele ocalało do dziś.

Adresatka listów Jasnorzewskiej, Rosa Bailly, to również poetka, ale przede wszystkim - niezmordowana propagatorka polskiej historii i kultury we Francji. Francuzka o polskim sercu, jak pisał o niej Tadeusz Domański². Obrończyni „,polskiej sprawy” zawsze i wszędzie tam, gdzie się taka konieczność pojawiała - od wspierania polskich starań o odzyskanie niepodległości w czasie pierwszej wojny światowej po upominanie się o polski Lwów po drugiej. Tłumaczka polskiej literatury. Założycielka, sekretarz generalna i główna animatorka stowarzyszenia Les Amis de la Pologne, istniejącego w latach 1919-1942. Niemal rówieśniczka Marii Jasnorzewskiej, urodzona 14 III 1890 (zm. 14 VI 1976), Rosa Bailly była w okresie międzywojennym niezwykle w Polsce popularną i szanowaną postacią, przyjeżdżała tu niemal co roku i znała prawie wszystkich. Pisarzy, artystów i polityków. Przyjmowali ją marszałek Piłsudski i prezydent Mościcki. Odwiedzała uniwersytety i salony, wygłaszała odczyty i chłonęła Polskę ${ }^{3}$.

1 Biblioteka Polska w Paryżu (dalej: BPP), Archiwum Rosy Bailly (dalej: ARB), akc. 2840.

2 T. D o m a ń s k i, Rosa Bailly: wielka Francuzka o polskim sercu. Lublin 2003.

3 O pracy stowarzyszenia Les Amis de la Pologne oraz o jego założycielce zob. A. Ło ng i e w s k a: Korespondencja Rosy Bailly z Felicja Skarbkowa z lat 1946-1959. „Ze Skarbca Kultury” z. 21 (1970); Francuzi w obronie prawa Polski do Górnego Śląska. „Kwartalnik Opolski” 1971, nr 3. - S. R o s p o n d, ,Les Amis de la Pologne” za polskim Górnym Śląskiem. „Kwartalnik Opolski" 1971, nr 3. - M. P a s z to r, O polsko-francuskiej wspótpracy kulturalnej i naukowej na przykladzie stowarzyszenia „Les Amis de la Pologne” w latach 1919-1924. „Kwartalnik Historii Nauki i Techniki" t. 37 (1992), nr 2. - D o mań sk i, op. cit. - A. Ko tań s k a, Ona była zakochana w Polsce. „Almanach Muzealny” t. 4 (2003). - A. P y t 1 a r z: Rosa Bailly - sa vie et ses liens d'amitié tissés avec la Pologne. „Synergies Pologne” 2003, nr 3; L'Oeuvre poétique de Rosa Bailly - la Pologne et la montagne. „Annales Academiae Pedagogicae Cracoviensis. Studia Romanica III” 2008. - M. N o s s o w s k a: „Listy do Polaków” Rosy Bailly jako odbicie losów polskich żolnierzy internowanych we Francji po czerwcu 1940 roku. „Annales UMCS”, Sectio F, t. 63 (2008); „Embarras de richesse", czyli historia rujnującego spadku. (Próby stworzenia przez Rosę Bailly ośrodka polskiego w Lechâtelet k. Dijon). „Dzieje Najnowsze” 2009, nr 1; Narodziny ,, siostry-cudzoziemki”, czyli o tym, jak Rosa stała się Różyczka. (Poczatki działalności Rosy Bailly na rzecz sprawy polskiej w latach I wojny światowej). „Annales UMCS”, Sectio F, t. 64 (2009); W poszukiwaniu nowych dróg 
Wiele łączyło obie damy i poetki. Poczucie bliskiego związku z naturą, szczególna wrażliwość i emocjonalność, które uczyniły z nich adeptki pióra i podopieczne Euterpe. Obie interesowały się zjawiskami nadprzyrodzonymi, Marię Jasnorzewską fascynowała magia, okultyzm, przepowiednie, świat pozazmysłowy, który pociągał również Rosę Bailly, obdarzoną przy tym zdolnościami radiestetycznymi i bioenergoterapeutycznymi ${ }^{4}$. Wszystko to stanowiło dość duży obszar, na jakim mogły zbliżyć się i porozumieć, a także nawiązać przyjaźń, która zaowocowała korespondencją. Podziwiały także nawzajem własną twórczość: Rosa Bailly bardzo ciepło pisała o poezji Jasnorzewskiej ${ }^{5}$, a ta ostatnia swój tomik Balet powojów, wydany w 1935 roku, zadedykowała właśnie Rosie, pozostając pod wrażeniem jej Montagnes Pyrénées - pierwszej części cyklu Fête de la terre ${ }^{6}$.

Trudno jednak stwierdzić dokładnie, gdzie i kiedy poznały się. Czy nastąpiło to w Polsce, podczas którejś z corocznych wycieczek Bailly, czy może w Paryżu, gdzie Pawlikowska również bywała? Czy poznały się w Krakowie? Czy w Warszawie, poprzez jednego ze skamandrytów? Może to Jan Lechoń, obdarzający przyjaznymi uczuciami obie panie i należący do kręgu ich bliskich znajomych, stał się pierwszym pośrednikiem w ich wzajemnych kontaktach? A może Boy, jak to sugeruje Elżbieta Hurnikowa w swojej monografii poświęconej Pawlikowskiej-Jasnorzewskiej? ${ }^{7}$ Wszystko to są spekulacje, pewne jest jednak, że wiele było miejsc i okazji, które sprzyjały nawiązaniu znajomości.

Wydaje się, że nastąpiło to raczej w Polsce, w której przyjazdy Rosy Bailly były odnotowywane i zauważane przez elity kulturalne ${ }^{8}$. Spotkania, przyjęcia, odczyty, towarzy-

- rzecz o reaktywacji stowarzyszenia Les Amis de la Pologne po zakończeniu II wojny światowej. „Dzieje Najnowsze” 2010, nr 2. - A. M. S t e f a n i c k a, Zapomniane listy z Coëtquidan. Warszawa 2009.

4 Rosa B a illy w trakcie jednego z pobytów w Polsce, w latach dwudziestych ubiegłego wieku, wykryła u siebie zdolności radiestetyczne, które w późniejszym, już powojennym okresie wykorzystywała jako dar uzdrawiania. Pisała o tym w książce Victoire sur le cancer (Genève 1969, s. 121-139), istnieje również bardzo liczna korespondencja poświęcona temu tematowi. Zob. m.in. W. Ła d a do R. Bailly: 14 i 27 II, 16 i 21 VII 1948 (BPP, ARB, akc. 2852). - R. B a illy do F. Skarbkowej: 15 VII 1948, 24 VI 1959 (w: Ł o n g i e w s k a, Korespondencja Rosy Bailly z Felicja Skarbkowa z lat 1946-1959). - R. B a i 11 y do M. Kuncewiczowej: 4 III 1953 (Zakład Narodowy im. Ossolińskich, rkps 16949/II). - R. B a illy do M. Kasprowiczowej: 18 XII 1957, 24 I, 25 II i 3 IV 1958 (Muzeum na Harendzie). - M. K a s p r o w i c z o w a do R. Bailly: grudzień 1957 (BPP, ARB, akc. 2833); 3 III i 7 VII 1959 (jw., akc. 2831). - R. B a i 11 y do M. Berezowskiej (kopia): 23 IX 1969 (jw., akc. 2897). - M. B e r e z o w s k a do R. Bailly: 18 IX, 2 i 10 X oraz 13 XI 1969 (jw.); 5 VIII 1970 (jw., akc. 2899); 28 IX 1970 (jw., akc. 2902).

5 R. B a illy, Maria Jasnorzewska (Pawlikowska). „Les Amis de la Pologne”. Bulletin mensuel, 1935, $\mathrm{nr}$ 8/9.

6 Warto dodać, że tomik Montagnes Pyrénées przyniósł Rosie Bailly nagrodę literacką i członkowstwo w Pirenejskiej Akademii Literatury.

7 E. Hurn i k ow a, Maria Pawlikowska-Jasnorzewska. (Zarys monograficzny). Katowice 1999, s. 287.

8 Każdej wizycie Rosy Bailly w Polsce towarzyszyły liczne artykuły w prasie, odnotowujące wszystkie wydarzenia kulturalne, wizyty, spotkania, w których ona uczestniczyła. Zob. m.in.: Rosa Bailly. „Kurier Poznański” 1921, nr z 20 IX. - W Tow. Polsko-Francuskim. „Kurier Warszawski” 1921, nr z 28 IX. - Rosa Bailly. „Tygodnik Ilustrowany” 1921, nr z 15 X. - Goście francuscy w Lublinie. ,Ziemia Lubelska” 1922, nry z 13 i 14 IX. - Wycieczki francuskie we Lwowie. „Kurier Lwowski” 1922, nr z 20 IX. - Z pobytu gości francuskich w Warszawie. „Kurier Warszawski” 1927, nr z 4 IX. - Les Amis de la Pologne we Lwowie. „Kurier Poranny” 1927, nr z 10 IX. - Wycieczka Tow. Przyjaciót Polski w Krakowie. „Czas” 1927, nr z 14 IX. - Wycieczka Tow. Przyjaciót Polski w Krakowie. „Ilustrowany Kurier Codzienny” 1927, nr z 14 IX. - A. R., Róża Bailly. „Bluszcz” 1927, nr z 17 IX. - D. M., Przyjaciółka Polski Rosa Bailly. „Kurier Poznański” 1929, nr z 8 VI. - Wizyta p. Rosy Bailly u prezydenta Warszawy. „Kurier Warszawski” 1929, nr z 15 VI. - Rosa Bailly w Polsce. „Kurier Warszawski. Niedzielny Dodatek Ilustrowany” 1929, nr z 16 VI. - 10 lat pracy stowa- 
szące jej za każdym razem zamieszanie, bliskie związki z Krakowem - nie mogły ujść uwagi Marii Pawlikowskiej, głęboko wrośniętej w artystyczne środowisko krakowskie, ale od połowy lat dwudziestych cenionej i sławnej też poza nim. Niewątpliwie już na początku lat trzydziestych Bailly znała zarówno Pawlikowską-Jasnorzewską, jak i jej (od 1931 roku) męża, Stefana Jerzego Jasnorzewskiego. Wtedy to zapewne nawiązała się pomiędzy paniami przynajmniej kilkuletnia korespondencja, której niewielki fragment przetrwał w archiwum Rosy Bailly.

Trzy listy pochodzą z końca roku 1935 i początku 1936; ich głównym tematem była praca Bailly nad tłumaczeniami wierszy Jasnorzewskiej oraz przygotowania, jak można wywnioskować, do wydania wyboru jej poezji we Francji. Projekt nie został ostatecznie zrealizowany, jednak w biuletynie stowarzyszenia Les Amis de la Pologne ukazało się kilka wierszy w przekładzie Bailly, a także jej bardzo ciepły i entuzjastyczny tekst na temat twórczości Jasnorzewskiej ${ }^{9}$. Bailly pisała w nim o zjawiskowej poetce, kobiecej i pięknej, kroczącej przez życie z pewnym nonszalanckim roztargnieniem, zachwycającej się naturą i podobnej do jednego z jej cudów, o oryginalnych wierszach, które urzekały swoją świeżością i delikatnością. A Jasnorzewska była zauroczona efektem pracy translatorskiej Rosy Bailly - podkreślała jej szczególne, jako poetki, kompetencje w tej dziedzinie i nadzwyczaj entuzjastycznie wyrażała się o pomyśle francuskiej edycji swoich wierszy ${ }^{10}$.

W jednym z listów z tego okresu pojawił się również bardzo osobisty motyw związany z pobytem Jasnorzewskich w Dęblinie, gdzie w 1934 roku przeniesiony został służbowo mąż Marii. Poetka wyjątkowo źle znosiła to miejsce, będące dla niej miejscem zesłania. Prymitywną pustynią pozbawioną elementarnych zdobyczy cywilizacji (np. dostępu do lekarza innego niż chirurg wojskowy... ${ }^{11}$ ), ale przede wszystkim pustynią ludzką. Hanna Mortkowicz-Olczakowa tak pisała w swoich wspomnieniach o Jasnorzewskiej:

tok jednostajnych dni w nieprzyjaznym środowisku. Żony oficerów inne, obce, często zawistne i pogardliwe. Lilka gorszyła je swoimi strojami, wierszami, jazdą na rowerze, brakiem umiejętności kulinarnych. Nie miała z nimi nic wspólnego. Opowiadała mi o tym swoim życiu prawie z płaczem ${ }^{12}$.

Gorycz i poczucie osamotnienia pojawiały się też w korespondencji z Rosą Bailly. Czwarty, ostatni list powstał w listopadzie 1939, w Bukareszcie, do którego rzuciły

rzyszenia Les Amis de la Pologne. „Kurier Poznański” 1929, nr z 17 VI. - Mity gość przyjaciel. Różyczka. „Ziemia Zachodnia” 1931, nr z 5 IX. - J. L e c h o ń, Ziemia z Verdun. „Gazeta Polska” 1935, nr z 1 IX. - Delegacja Les Amis de la Pologne przybywa do Polski. „Kurier Polski” 1935, nr z 3 IX. - Francuscy Przyjaciele Polski w Warszawie. „Kurier Poranny” 1935, nr z 5 IX. - Piękna manifestacja przyjaźni polsko-francuskiej. „Czas” 1935, nr z 5 IX. - Wielka manifestacja przyjaźni polsko-francuskiej. „Gazeta Polska” 1935, nr z 5 IX. - Wycieczka francuska u prezydenta miasta. „Kurier Poranny” 1935, nr z 6 IX. - Jubileusz pani Rosy Bailly. „Czas” 1936, nr z 18 IX. - Jubileusz Rosy Bailly. „Kurier Warszawski” 1936, nr z 18 IX. - Uczczenie zastug p. Rosy Bailly. „Ilustrowany Kurier Codzienny” 1936, nr z 18 IX. - Akademia ku czci zastużonej przyjaciótki Polski. „Ilustrowany Kurier Codzienny” 1936, nr z 19 IX. - Jubileusz Rosy Bailly. „Kurier Poranny” 1936, nr z 19 IX. - Dekoracja Rosy Bailly orderem Polonia Restituta. „Kurier Poranny” 1936, nr z 23 IX. - J. W i e1 e ż y ń s k a, Rose Bailly. „Bluszcz” 1936, nr z 26 IX.

${ }^{9} \mathrm{~B}$ a illy, Maria Jasnorzewska (Pawlikowska). - M. J a s n o r z e w s k a: Le Bandit et le diable [Bandyta i diabet, z tomu Wachlarz]. „Les Amis de la Pologne” 1935, nr 8/9; Épingles [Szpilki, z tomu Wachlarz]. Jw.; Le Chant du rossignol [Śpiew słowika, z tomu Wachlarz]. Jw., 1938, nr 5; L'Aigre brodeuse [Kwaśna hafciarka, z tomu Balet powojów]. Jw., 1939, nr 2; Le Ciel et les chapeaux [Niebo a kapelusze, z tomu Różowa magia]. Jw.

${ }_{10}$ Zob. publikowane tu listy z 12 i 26 XI 1935.

11 Zob. list z 30 III 1936.

${ }_{12}$ H. Mortkowicz-O lc zakow a, Bunt wspomnień. Warszawa 1961, s. 191. Zob. też Hurnikowa, op. cit., s. 295. 
Jasnorzewską wojenne losy. Opuściła ona Polskę wraz z mężem, jadąc przez Lwów i Zaleszczyki, szlakiem tysięcy uchodźców, by najpierw dotrzeć do Rumunii, a później, przez Rzym, Francję - pierwotny punkt docelowy ewakuacji - do Anglii, gdzie znalazła się wreszcie na przełomie czerwca i lipca 1940. W Bukareszcie Jasnorzewska zatrzymała się u Duszy Czary-Stec, rumuńskiej poetki, literatki i tłumaczki, którą znała jeszcze sprzed wojny, ale mimo jej namów, by pozostała w Rumunii, była zdecydowana towarzyszyć mężowi w dalszej tułaczce ${ }^{13}$. Jest to list ,z drogi” w sensie dosłownym i przenośnym, list z okresu starań o wyjazd do Francji, okresu zawieszenia i niepewności, list, w którym poetka opisuje swoje nadzieje i kłopoty z podróżą związane. Widać w nim także częściowo rolę, jaką w przygotowaniu pobytu Jasnorzewskich w Paryżu odgrywała Bailly.

W papierach Rosy Bailly nie zachowało się więcej śladów przyjaźni i korespondencji z Pawlikowską-Jasnorzewską ${ }^{14}$, mimo że listów musiały obie damy wymienić dużo więcej, co wynika chociażby z treści tych, które przetrwały. Zaginęły one, być może, podobnie jak wszystkie listy Tadeusza Boya-Żeleńskiego do Rosy Bailly ${ }^{15}$, w czasie jej pospiesznej ewakuacji z Paryża w czerwcu 1940 lub w trakcie dewastacji lokalu stowarzyszenia Les Amis de la Pologne dokonanej przez gestapo po zajęciu Paryża przez Niemców. Tym cenniejsze wydają się te cztery cudem ocalone, które mimo, iż są fragmentem wyrwanym z długiego dialogu, dają piękne świadectwo przyjaźni tych dwóch niezwykłych kobiet. Jeszcze wiele lat po śmierci polskiej poetki Rosa Bailly z wielką atencją, serdecznością, z ogromną przyjaźnią wspominała swoją z nią znajomość ${ }^{16} \mathrm{i}$ była jedną z pierwszych osób, które wsparły akcję zbierania funduszy na ochronę jej grobu ${ }^{17}$.

Listy są tu przedstawione w wersji oryginalnej oraz w thumaczeniu na język polski. W tekstach francuskich zachowano składnię i ortografię autorki. Pozostawiono też uczynione w języku polskim dopiski Stefana Jerzego Jasnorzewskiego. Daty listów konsekwentnie umieszczono po prawej stronie, choć w dwóch listach znajdowały się po lewej. Ujednolicono również układ podpisów - zawsze po prawej stronie.

${ }_{13}$ Zob. Hurnikow a, op. cit., s. 361-365. - M. S a mo z w a n i e c, Zalotnica niebieska. Szczecin 1988, s. 294.

${ }_{14}$ Zachowała się jeszcze koperta (bez listu) datowana stemplem pocztowym 23 X 1939, z adresem wpisanym ciemnogranatowym atramentem:

madame Rosa Bailly

Société des Amis de la Pologne

3 Rue de L'Abbé de L'Épée nr 16 Paris V

France

Na odwrocie adres nadawcy:

Maria Jasnorzewska

București (Cotroçeni)

str. Dr. Herescu

Chez mme Czara-Stec

W opracowanym i opublikowanym przez K. Olszańskieg o tomie listów poetki (M. z K o s s a kó w J a s n o r z e w s k a, Listy do przyjaciół i korespondencja z mężem 〈1928-1945〉. Kraków 1998) znajduje się tylko jedna jej wzmianka na temat Bailly: w liście do męża z 1 XI 1944.

${ }_{15}$ Zob. B. Wi nklow a: list do R. Bailly, z 9 II 1967. BPP, ARB, akc. 2824; wstęp w:

T. B o y - Że l eń s k i, Listy. Oprac. ... Warszawa 1972, s. 10.

${ }_{16}$ Zob. B. O b e r t y ń s k a: Korespondencja. T. 1. Bibl. Jagiellońska, rkps przyb. 475/05 (list R. B ailly z 7 XII 1969); Bruliony i kopie listów. T. 1. Jw., rkps przyb 504/05 (brulion listu do R. Bailly z 13 XII 1969).

17 Zob. B. O b e r ty ń s k a, Lilka. „Wiadomości” (Londyn) 1969, nr z 23 XI. 
$12 / 11 / 35$

Dęblin-Lotnisko poczta Irena

Ma Rose adorée!

Tu dois me juger mal, et c'est injuste, crois-moi ma chérie! Notre excursion expira le I octobre - mais nous avions encore un mois de congé, nous avons passé à Cracovie et à la campagne et Tes chères lettres et les numéros de Ton magnifique mensuaire, ou m'attendait la grande surprise, restaient à Dęblin. Maintenant, à mon retour dans ces parages, je les trouve hélas si tard! J'embrasse mille fois Ton souvenir, car Tu est unique, Rosa. Gentille, et grande, et si douce, si bonne. Comment va Ta santé, dis mon aimée? Ne croit pas trop aux médecins, surtout repose Toi! Si Tu pouvais venir à Zakopane ou à Krynica, qui sont si réconfortantes! Immédiatement je Te rejoindrai.

Comme on a lieu traduit mes poèmes - est-ce Toi, Rosa, qui a fait cela? Si c'est vrai, je Te félicite, car ils me paraissent mieux qu'en origine.

Les vers $d u$ " Ballet » c'est entendu, je les " prosifiés » en français et je les envois bien vite. A présent je me dépêche pour que Tu ne pense pas mal de nous deux, ou ce qui serait encore pire, que Tu ne nous oubliasses. Je joint une dernière photo de mon mari qui T'adore, faite à Cracovie dans notre native "Kossakówka » et souvient Toi, chère âme, que nous sommes ensemble à Toi.

Je T'embrasse, en priant humblement des nouvelles de Ta chère santé.

Quand nous reverrons nous?

Do widzenia, droga Różyczko

Bądź zdrowa, kochanie

Marie Jasnorzewska

Jestem pod Pani urokiem. Proszę o pamięć, czekam na chwilę, kiedy Panią znowu zobaczę. Votre humble serviteur.

Jasnorzewski

$12 / 11 / 35$

Dęblin-Lotnisko

poczta Irena ${ }^{1}$

Moja ukochana Roso!

Na pewno źle o mnie myślisz, ale to niesprawiedliwe, zapewniam Cię moja droga! Nasza wycieczka skończyła się 1 października - ale mieliśmy jeszcze miesiąc urlopu, spędziliśmy go w Krakowie i na wsi i Twoje drogie listy oraz egzemplarze Twojego wspaniałego miesięcznika, w których czekała na mnie ogromna niespodzianka ${ }^{2}$, zostały w Dęblinie. Teraz, po moim powrocie w te strony, znalazłam je, niestety, tak późno! Całuję tysiąc razy upominek od Ciebie, bo jesteś wyjątkowa. Szlachetna i wielka, i tak delikatna, tak dobra. Jak Twoje zdrowie, moja kochana? Nie ufaj zbytnio lekarzom, przede wszystkim odpoczywaj! Gdybyś mogła 
przyjechać do Zakopanego albo do Krynicy, postawiłoby Cię to na nogi! Natychmiast dołączę do Ciebie.

Co do tłumaczenia moich wierszy - to Ty je zrobiłaś? Jeśli tak, to gratuluję $\mathrm{Ci}$, ponieważ wydają mi się lepsze od oryginału.

Wiersze Baletu ${ }^{3}$, to postanowione, ,,przekładam” na prozę po francusku i bardzo szybko [Ci] je wysyłam. Spieszę się teraz, żebyś nie myślała o nas źle albo, co byłoby jeszcze gorsze, żebyś nas nie zapomniała. Dołączam ostatnie zdjęcie mojego męża ${ }^{4}$, który Cię uwielbia, zrobione w Krakowie, w naszej rodzinnej „Kossakówce”, i nie zapominaj o tym, duszko, że zawsze jesteśmy oboje z Tobą.

Całuję Cię, prosząc pokornie o wieści o Twoim kochanym zdrowiu.

Kiedy zobaczymy się znowu?

Do widzenia, droga Różyczko

Bądź zdrowa, kochanie

\section{Maria Jasnorzewska}

Jestem pod Pani urokiem. Proszę o pamięć, czekam na chwilę, kiedy Panią znowu zobaczę. Pani pokorny sługa.

\section{Jasnorzewski}

Karta formatu A4, złożona na pół, tworząca 4 stronice, zapisane czarnym atramentem, wyraźnym, okrągłym pismem. Papier kremowy, pożółkły. Dopisek Jasnorzewskiego atramentem o intensywniejszej czerni, pismo pochyłe, ostrzejsze, mniej wyraźne.

1 Właściwa nazwa lotniska wojskowego brzmiała: Dęblin-Irena.

2 Chodzi o numer 8/9 biuletynu „Les Amis de la Pologne”, w którym opublikowany został wspomiany już tu tekst Bailly o poezji Jasnorzewskiej oraz jej dwa wiersze: Le Bandit et le diable i Épingles.

3 Mowa o tomiku Balet powojów.

4 Zdjęcie zachowało się.

Rosa, ma grande chérie

je suis complètement émerveillée de Tes traductions. C'est pour moi une chance inespérée d'avoir pour traducteur non seulement une vraie Française mais en outre une géniale artiste. Cette idée, de me présenter à la chère France, habillée par Toi comme par une fée, me plait joliment! C'était toujours mon désir, car (étant conçue à Paris, ne ris pas, ma chère!) je ressent souvent la nostalgie de ma seconde patrie.

Traduis autant que Tu pourras, je T'en prie! Je T'envoie encore une autre plaquette. Pour celle-là j’ai reçu un prix du «Związek Literatów Polskich ».

J'ai désignées quelques pieces, au crayon, s'il Te plaisait de les traduire, cela me fairait grand plaisir.

Tu donnes à mes vers un charme bizarre, un ton inédit.

Seulement cette "Cathon 》 me paraît trop ressemblante à Caton, peut-être "Kasia » tout simplement, Marion, Sophie, quelque nom de femme de chambre de la campagne française populaire, ou purement polonaise. Tu trouveras dans "l'équipage endormi » "Spiaca załoga » deux vers - traduit par moi. Corriges- 
-les, ou refaits les, ou rejettes les, bien? Je sens qu'un Français, en les lisant va bien pouffer de rire - et ce n'est pas mon but.

Tiens-moi au courrant, ma Rosa, de ce charmant projet. Salut à Lechoń.

Dieu veuille qu'il nous ailles!

Comme je voudrais te revoir. Tu es une enchanteresse.

Toute à Toi

Marie [dopisek Rosy Bailly: Jasnorzewska Pawlikowska]

J'envoie une photo, et le livre ensemble

[Dopisek na marginesie:] Les fautes que j'ai faites dans cette lettre me font mal! Je T'en prie, aimée Rosa, pardonne moi.

26/11/[1]935

Moja bardzo kochana Roso,

Jestem całkowicie zauroczona Twoimi thumaczeniami. To dla mnie nieoczekiwane szczęście: mieć jako tłumacza nie tylko prawdziwą Francuzkę, ale przede wszystkim genialną poetkę. Ten pomysł, aby pokazać kochanej Francji mnie, ustrojoną przez Ciebie jak przez wróżkę, podoba mi się bardzo. To było zawsze moim pragnieniem, ponieważ (będąc poczętą w Paryżu, nie śmiej się moja droga!') odczuwam często nostalgię za moją drugą ojczyzną.

Przełóż tyle, ile będziesz mogła, proszę Cię! Wysyłam Ci jeszcze inny tomik, za który właśnie otrzymałam nagrodę Związku Literatów Polskich².

Zaznaczyłam kilka fragmentów ołówkiem, gdybyś zechciała je przełożyć, sprawiłoby mi to ogromną przyjemność.

Dajesz mojej poezji przedziwny urok, nowe brzmienie.

Tylko ta "Cathon” wydaje mi się zbyt podobna do Katona, może całkiem zwyczajnie „Kasia”, Marion, Zofia, jakieś imiona pokojówek z francuskiej wsi lub czysto polskie. Znajdziesz w Śpiacej załodze dwa wiersze - przetłumaczone przeze mnie. Popraw je albo przerób, albo wyrzuć, dobrze? Czuję, że Francuz, czytając je, parsknie śmiechem - a to nie jest moim celem.

Informuj mnie na bieżąco, moja Roso, o tym uroczym projekcie. Pozdrowienia dla Lechonia ${ }^{3}$.

Niech Bóg sprawi, żeby nam się powiodło!

Jakże chciałabym zobaczyć Cię znowu. Jesteś czarodziejką.

Cała Twoja

Maria [dopisek Rosy Bailly: Jasnorzewska Pawlikowska]

Przesyłam [Ci] fotografię, i książkę razem

Błędy, które zrobiłam w tym liście, sprawiają mi cierpienie! Proszę Cię, kochana Roso, wybacz mi.

Karta formatu A4, zapisana dwustronnie czarnym atramentem, pismem wyraźnym, okrągłym, trochę „dziecinnym”; papier pożółkły, przypuszczalnie pierwotnie jasnokremowy.

1 Nie jest jasne, co autorka listu miała na myśli. Wydaje się, że był to jeden z elementów legendy autobiograficznej (jej ważnymi składnikami były również czas i okoliczności przyjścia na świat) budowanej przez Pawlikowską-Jasnorzewską przez większą część życia. Zob. H u r n i k o w a, op. cit., s. 18-19, 363.

2 Chodzi o tom Śpiaca załoga, wydany w 1932 roku. 
3 W latach 1930-1939 Jan Le choń był radcą kulturalnym ambasady polskiej w Paryżu i utrzymywał ciepłe i dość bliskie relacje z Rosą Bailly, z którą z racji swojej funkcji i jej pracy często stykał się niejako służbowo.

Dęblin Lotnisko p[oczta] Irena $30 / \mathrm{III} / 36$

Najdroższa Rosa!

Ma chérie, mon ange, ta douceur m'étrangle! Tu es trop charmante pour Ta pauvre amie. Je me sens mieux, et je me mets au travail, depuis demain. Les dernières traductions, surtout le "rossignol » sont surp re na n tes. En général, toutes me plaisent - il y a une chose: beaucoup de mes poésies sont pour moi surannées, et très désagréables pour moi; je comprends autrement la poésie maintenant. Ce sont celles de la "Magie rose», et plusieurs quatrains naïfs, que je Te demanderais de rejetter. Mais je ne aurais jamais rêver une meilleurs traduction-d'abord Tu es Toi même une ensorceleuse, une Sapho, et en surplus Tu m'aime un peu. Cela fait ensemble des condition rares à trouver en ce monde.

Ne me crois donc pas si bête de ne pas comprendre le bonheur qui m'arrive. Hélas, j'ai passée par de cruelles épreuves, et la vie est devenue pour moi un petit enfer. J'avais terriblement mal à la gorge pendant trois semaines (une angine chronique) et j'ai souffert beaucoup, seule sans médecin, en ce lieu sauvage ou il n'y a qu'un chirurgien pour les cas graves, j'ai eu peur, surtout la nuit de m'étrangler, j'ai ennuyée mon mari, j'ai perdus 5 kilos, enlaidie, jaunie, sans aucune envie de travailler. Figure Toi, que c'est connu ici: les marécages et les brumes font de Dęblin un lieu d'exportation. On m'a fait exprès cela - en général si Tu savais comme on me traite ici! Moi, qui a tant écris pour ces gens, je suis ignorée absolument, aucun aviateur ne vient me voire, au contraire, sans cesse on me prend mon mari, pour le bridge, lui apprenant à me laisser toute seule dans ce désert ou il y a que la lune et des chiens hurlant, depuis la tombée du jour. Ingrat Pologne, pour Toi, son Amie chaude et sans pareille, pour moi, sa fille qui aimait tant son "polskie lotnictwo ", et qui perds sa santé dans un trou terrible, ou elle partage le sort de son mari (qui depuis son mariage avec moi n'avance plus, reste lieutenant, malgré toute sa bravoure, son énergie et ses dix années consacrées à l'aviation!) personne ne me croirait: Toi, qui connait le caractère bizarre de mon intéressante nation, Tu ne me diras pas: Tu exagères! Et encore, pense seulement, mon mari, lui, souffre de ce climat et je ne peut rien pour lui.

Demain, je relirais attentivement toutes les pages que Tu m'a données - je les embrasserais et je t'enverrais après demain (comme je t'aime!). Cette lettre est une avantgarde, (et un long baiser sur ta joue rose et charmante). Je t'adore comme femme et comme poète, et crois moi - no tre livre sera bi e n. Ta préface me sera une jolie et un honneur. Je ne peut pas trouver la plaquette "Biała dama», mais je Te copierais par cour les meilleures horreurs.

Toute à Toi à jamais

Marie Jasnorzewska Pawlikowska (Jasnorzewski Te baise les mains) 
Dęblin-Lotnisko, p[oczta] Irena $30 / \mathrm{III} / 36$

Najdroższa Roso!

Moja droga, mój aniele, twoja dobroć sprawia, że wzruszenie ściska mi gardło! Jesteś zbyt dobra dla swojej biednej przyjaciółki. Czuję się lepiej i od jutra zabieram się do pracy. Ostatnie thumaczenia, przede wszystkim Stowik', są z a d z iw i a ją c e. W zasadzie, wszystkie mi się podobają - tylko jedna sprawa: wiele moich wierszy jest według mnie przestarzałych i obcych mi, poezję teraz rozumiem inaczej. To są te wiersze z Różowej magii i wiele innych naiwnych wierszyków, które prosiłabym Cię, żebyś wyrzuciła. Ale nie mogłabym nigdy marzyć o lepszym tłumaczeniu - przede wszystkim dlatego, że jesteś po prostu czarodziejką, Safo, a w dodatku lubisz mnie troszkę. To razem stwarza sytuację rzadko zdarzającą się na tym świecie.

Nie sądź więc, że jestem aż tak głupia, żeby nie rozumieć szczęścia, które mnie spotyka. Niestety, przeszłam straszne rzeczy, i życie stało się dla mnie małym piekłem. Okropnie chorowałam na gardło przez trzy tygodnie (przewlekła angina) i bardzo cierpiałam, sama, bez lekarza, w tym dzikim miejscu, gdzie jest wyłącznie chirurg do ciężkich przypadków. Bałam się, że uduszę się w nocy, umęczyłam mojego męża, schudłam 5 kilo, zbrzydłam, pożółkłam, straciłam chęć do pracy. Wyobraź sobie to, o czym wszyscy wiedzą: bagna i mgły czynią z Dęblina miejsce zesłania. Zrobiono mi to celowo - zresztą gdybyś wiedziała, jak mnie tu traktują! Ja, która tyle napisałam dla tych ludzi, jestem tu całkowicie ignorowana, żaden z lotników nie odwiedza mnie, przeciwnie, bezustannie zabierają mi mojego męża, na brydża, każąc mu zostawiać mnie całkiem samą na tej pustyni, gdzie tylko księżyc i wyjące psy, od zmierzchu. Niewdzięczna Polska - dla Ciebie, jej gorącej przyjaciółki i, bez porównania, dla mnie, jej córki, która tak kochała „,polskie lotnictwo" i która traci zdrowie w tej strasznej dziurze, gdzie dzieli los swego męża (którego od chwili małżeństwa ze mną pozbawia się awansu, pozostaje on porucznikiem, mimo swojej odwagi, energii i dziesięciu lat poświęconych lotnictwu! ${ }^{2}$ ). Nikt nie uwierzyłby mi: Ty, która znasz dziwny charakter mojego wyjątkowego narodu, nie powiesz mi: przesadzasz! I jeszcze, pomyśl tylko, mój mąż cierpi w tej atmosferze i nie mogę nic dla niego zrobić.

Jutro przeczytam jeszcze raz uważnie wszystkie kartki, które mi przysłałaś ucałuję je i wyślę pojutrze (jakże Cię kocham!). Ten list jest forpocztą (i długim pocałunkiem na Twoim różowym i uroczym policzku). Uwielbiam Cię jako kobietę i jako poetkę i uwierz mi - n a s z a książka będzie d o bra. Twoja przedmowa sprawi mi radość i zaszczyt. Nie mogę znaleźć tomiku Biała dama, ale odtworzę Ci z pamięci najlepsze opowieści grozy.

Twoja na zawsze

Maria Jasnorzewska Pawlikowska (Jasnorzewski całuje Twoje dłonie)

Karta formatu A4, zapisana dwustronnie na maszynie, z odręcznymi poprawkami (interpunkcja, akcenty); podpis odręczny.

1 Chodzi o wiersz Śpiew stowika.

2 O trudnościach $\mathrm{z}$ awansem Jasnorzewskiego oraz o jego staraniach o uzyskanie lepszego 
przydziału wojskowego zob. Hurnik ow a, op. cit., s. 233. - M. S a mozw an i e c, Maria i Magdalena. T. 2. Pruszków 1992, s. 233-234.

4

$28 / 11 / 39$

Chère Różyczka, douce amie!

Je Te suis reconnaissante au-delà de toute expression que Tu as déjà pensée à notre logement. Nous étions déjà prêts à partir quand des affaires urgentes nous on retenues, pour une semaine encore. Mais nous viendrons pour sure. Nous allons en auto - arrivés en France nous télégraphierons pour que Tu saches le jour de notre arrivée. Je voudrais être au plus vite près de Toi pour te soigner, car je connais des moyens excellents pour guérir le cour malade - nous avons tant et tout à nous dire, et peut-être pourrais - je T'aider dans tes travaux pour les affaires polonaises. J'aurais avec moi une machine à écrire, je serais volontiers ta secrétaire, Tu me dicteras Tes merveilles de poésies, en Te reposant. Chère Rosa, je Te prie, ne Te fatigue pas. Tu es l'amour de la Pologne, il faut vivre pour la revoir encore; cette maladie est passagère, il faut absolument rester couchée au moins trois semaines, boire peu de boissons et ne pas manger de viande du tout, prendre du miel autant que Tu peux et faire des compresses froides sur le cour. Mélanger un peu de jodine avec de la vaseline, 5 gouttes de jodine pour cuillère à soupe de vaseline ou d'huile d'olive et frictionner le côté gauche, et le dos du côté gauche.

C'est un moyen capital. La camomille en place du thé-et pas de bains chauds. Une douche chaude tout au plus.

Le reste, je te le dirais, en Te serrant sur mon cour, Różyczka, à laquelle je voudrais consacrer mon séjour en France.

Dis à ta comtesse que je l'aime d'avance pour sa gentillesse; Tu dis que la chambre est chaude - quelle chance! Car à Paris ou gèle beaucoup pendant l'hiver. Fais aussi attention à cela-le cœur aime la douce température et déteste les courrant-d'air.

Au revoir, Różyczka; l'assurance de mon amour, de mon respect, sois bonnes pour Toi!

Lilka

Rączki całuję mocno i gorąco. Proszę nie chorować. Dużo miłych i serdecznych słów załączam

Jerzy

$28 / 11 / 39$

Droga Różyczko, słodka przyjaciółko!

Jestem Ci wdzięczna ponad wszelkie wyobrażenie, że pomyślałaś już o mieszkaniu dla nas. Byliśmy już gotowi do wyjazdu, kiedy nagłe sprawy zatrzymały nas jeszcze na tydzień. Ale zjawimy się na pewno. Jedziemy autem - po przyjeździe do Francji zatelegrafujemy, żebyś znała datę naszego przyjazdu. Chciałabym być jak najszybciej przy Tobie, żeby opiekować się Tobą, ponieważ znam wspaniałe 
metody, żeby uzdrowić chore serce - mamy sobie tyle do opowiedzenia i, być może, mogłabym pomóc $\mathrm{Ci}$ w Twoich polskich pracach, będę miała ze sobą maszynę do pisania i chętnie zostanę Twoja sekretarką. Będziesz odpoczywając dyktować mi swoje poetyckie cudowności. Droga Roso, proszę Cię, nie przemęczaj się. Kochasz Polskę, trzeba żyć, żeby ją znowu zobaczyć; ta choroba jest przejściowa, trzeba koniecznie zostać w łóżku co najmniej trzy tygodnie, pić mało i wcale nie jeść mięsa, zażywać miodu tyle, ile możesz, i robić zimne okłady na serce. Wymieszać trochę jodyny z wazeliną, 5 kropli jodyny na łyżkę do zupy wazeliny albo oliwy z oliwek i nacierać lewy bok i lewą stronę pleców.

To główny sposób. Rumianek w miejsce herbaty - i żadnych ciepłych kąpieli. Ciepły prysznic co najwyżej.

Resztę opowiem przyciskając Cię do serca, Różyczko, Tobie chciałabym poświęcić mój pobyt we Francji.

Powiedz swojej hrabinie, że już ją kocham za jej szlachetność. Mówisz, że pokój jest ciepły - co za szczęście! Zwłaszcza w Paryżu, gdzie mrozi bardzo w czasie zimy. Sama też uważaj na to - serce lubi umiarkowane temperatury i nie znosi przeciągów. siebie!

Do widzenia, Różyczko; zapewnienia mojej miłości, szacunku, bądź dobra dla Lilka

Rączki całuję mocno i gorąco. Proszę nie chorować. Dużo miłych i serdecznych słów załączam

Jerzy

Karta formatu A4, złożona na pół, tworząca 4 stronice, zapisane czarnym atramentem, wyraźnym, okrągłym pismem.

\author{
Abstract \\ MARIA PAWLIKOWSKA-JASNORZEWSKA'S FOUR UNKNOWN LETTERS \\ FROM THE YEARS 1935-1939
}

Translated and edited by MAŁGORZATA NOSSOWSKA

(Maria Curie-Słodowska University, Lublin)

The four letters by Maria Pawlikowska-Jasnorzewska (1891-1945) to Rosa Bailly (1890-1976), a French poetess, Polish literature translator, founder of Les Amis de la Pologne association, attest to the friendship the two women developed in the 1930s, to their intimacy and reciprocal admiration of one another's poetry. The letters, making up a fragment of their correspondence, have survived in Rosa Bailly's archive in The Polish Library in Paris. Three of the aforementioned letters date back to 1935 and 1936 and touch upon first and foremost the translation of Pawlikowska-Jasnorzewska's poems into French and her family situation after Maria's marriage to Stefan Jerzy Jasnorzewski, while the fourth letter, dated November 1939, is devoted to the plans of leaving Romania for Paris. 